\title{
Bioefikasi Neurotoksin Ekstrak Campuran Daun Permot dan Batang Sereh Bentuk Semprot terhadap Kecoa Jerman (Blattella germanica)
}

\author{
Flora Rumiati ${ }^{1}$, Rina Priastini Susilowati ${ }^{2}$, Sancia Nathania Legenie Banuang ${ }^{3}$
}

${ }^{1}$ Departemen Fisiologi, Fakultas Kedokteran dan Ilmu Kesehatan, Universitas Kristen Krida

Wacana, Jakarta, Indonesia

${ }^{2}$ Departemen Biologi, Fakultas Kedokteran dan Ilmu Kesehatan, Universitas Kristen Krida Wacana, Jakarta, Indonesia

${ }^{3}$ Fakultas Kedokteran dan Ilmu Kesehatan, Universitas Kristen Krida Wacana, Jakarta, Indonesia Alamat Korespondensi: flora.rumiati@ukrida.ac.id

\begin{abstract}
Abstrak
Kecoa Jerman (Blattella germanica) merupakan salah satu hama pembawa penyakit, yang dapat diatasi dengan insektisida yang efektif, aman dan tidak bersifat resistensi. Bahan kimia aktif yang bersifat neurotoksin dalam ekstrak daun permot (Passiflora foetida) seperti ermanin, vitexin, harmalin, harmin, dan kandungan minyak atsiri pada daun dan batang sereh (Cymbopogon nardus) dapat digunakan sebagai insektisida tersebut. Tujuan penelitian untuk mengetahui bioefikasi pemberian ekstrak daun permot dan daun batang sereh terhadap mortalitas kecoa Jerman. Penelitian ini menggunakan metode eksperimental. Sampling dihitung dengan rumus Federer. Kecoa Jerman ditempatkan pada enam kandang sesuai kelompok perlakuan dengan 5 kali ulangan. Kelompok perlakuan adalah kontrol negatif (tanpa paparan), kontrol positif (disemprot dengan insektisida sintetik berbahan praletin $0,170 \%$, d-alletrin $0,135 \%$ dan sipermetrin $0,100 \%$ ), campuran ekstrak daun permot dan daun batang sereh $(500,1000,2000$, dan 4000 ppm). Pengamatan dilakukan setelah 10 menit pertama penyemprotan, dilanjutkan tiap jam selama 6 jam dan 24 jam. Kecoa dinyatakan mati jika badan terbalik dan tidak ada gerakan. Dari hasil penelitian diperoleh nilai $\mathrm{LC}_{50}$ sebesar $341 \mathrm{ppm}$, dan nilai $\mathrm{LC}_{90}$ sebesar 1175 ppm. Berdasarkan uji one way Anova terdapat perbedaan bermakna antara kelompok kontrol dengan kelompok perlakuan. Dapat disimpulkan bahwa campuran daun permot dan daun batang sereh memiliki efek neurotoksik yang mematikan pada kecoa Jerman.
\end{abstract}

Kata kunci: Blatella germanica, Cymbopogon nardus, mortalitas, neurotoksin, Passiflora foetida

\section{Bioefication of Neurotoxin Spray Made of Extracts of Permot Leaf and Lemongrass Stem against German Cockroaches (Blattella germanica)}

\begin{abstract}
The German cockroach, Blattella germanica is one of many pests that act as disease carriers in the intestine. Controlling the cockroach population requires insecticidal efficacy. The organic insecticides contain ermanin, vitexin, harmaline, harmine on permot, a neurotoxin, and essential oils from lemongrass. The current study investigated the effectiveness of the administration of permot leaves and lemongrass stem leaves to the mortality of the German cockroaches. The German cockroaches were divided into 6 groups, each with 5 replications, as follows: a negative control (without exposure) and a positive control (sprayed with synthetic insecticide containing praletin $0.170 \%$, D-Alethrin $0.135 \%$ and sipermetrin $0.100 \%)$. Treatment groups were treated with extract prepared from a mixture of permot leaf and lemongrass stem leaves (500, 1000, 2000 and 4000 ppm). Observations were made at 10 minutes after spraying, every hour for 6 hours and after 24 hours. Cockroaches were declared dead if their bodies were discovered upside down and there was no movement. The study found significant differences (one-way ANOVA) between control and treatment groups. The LC50 and LC90 of the extract were 341 and 1175 ppm, respectively. The study concludes a mixture of permot leaves and lemongrass stem leaves has a toxic effect on German cockroaches.
\end{abstract}

Keywords: Blatella germanica, Cymbopogon nardus, mortality, neurotoxin, Passiflora foet 


\section{Pendahuluan}

Indonesia merupakan negara beriklim tropis yang memiliki kekayaan alam flora dan fauna. Sebagai negara berkembang, faktor kebersihan lingkungan sangat bepengaruh pada kehidupan kesehatan masyarakat. Salah satu spesies yang mempengaruhi kebersihan lingkungan adalah kecoa, dan yang paling sering ditemui adalah Kecoa Jerman (Blattella germanica). Kecoa jerman dapat berperan sebagai vektor penyakit, karena suka berada pada lingkungan yang gelap, lembab, dan kotor sehingga akan membawa suatu kuman penyebab suatu penyakit yang tertempel dan terbawa oleh tubuhnya. ${ }^{1,2}$

Penyakit yang ditularkan oleh kecoa antara lain disentri, kolera, typhus perut, diare dan lainnya yang berkaitan dengan kondisi sanitasi lingkungan yang buruk. ${ }^{3,4}$ Penggunaan insektisida berbahan piretroid sintetis yang terus menerus dapat menyebabkan resistensi pada kecoa. Oleh karena itu perlu dicari bahan kimia aktif alternatif yang berfungsi sebagai insektisida alami terhadap kematian kecoa Jerman, tanpa menyebabkan resistensi, aman digunakan dan tidak menyebabkan polusi pada lingkungan.

Senyawa bioaktif pada tumbuhan yang diduga berfungsi sebagai insektisida diantaranya golongan sianida, saponin, tannin, flavonoid, alkaloid, steroid dan minyak atsiri. Di antara berbagai tanaman yang dapat digunakan sebagai bahan aktif insektisida adalah daun permot (Passiflora foetida) dan daun batang serai wangi (Cymbopogon nardus) dengan cara di ekstrak campuran dengan bahan kedua tanaman tersebut. ${ }^{1,2}$

Tanaman permot (Passiflora foetida) dapat dijumpai di sawah, kebun, atau merambat di sela tanaman utama, atau pada tanah lapang. ${ }^{5}$ Daun permot ini mengandung asam hidrosianat, flavonoid (ermanin dan vitexin), alkaloid (harmalin, harmin, harmol), saponin (saponaretin, saponarine), passifloracine. Vitexin, harmalin dan harmin bersifat neurotoksin, yang akan menyebabkan gangguan pada saraf. Alkaloid, flavonoid, saponin pada daun permot mampu bekerja sebagai racun pada larva nyamuk baik sebagai racun kontak maupun racun perut sehingga daun permot baik digunakan sebagai bahan larvasida yang berguna untuk membasmi larva $A e$. aegypti. ${ }^{6,7}$

Kandungan ekstrak dari permot seperti ermanin, vitexin, harmalin, harmin dapat memperlambat penutupan channel dan akan mengakibatkan saraf menjadi keadaan depolarisasi cukup lama, sehingga ion $\mathrm{Na}^{+}$masuk terlalu banyak ke dalam membran. Mekanisme kerja racun kontak menghambat enzim asetilkolinesterase, maka akan menyebabkan gejala yang muncul seperti kejang dan gemetar. Ermanin, harmalin, harmin dapat juga menghalangi terjadinya penutupan saluran, sehingga pada keadaan ini dapat menyebabkan membran kelebihan ion $\mathrm{Na}^{+}$yang nanti pada akhirnya saraf menjadi tidak aktif. Ketidakaktifan saraf ini dikarenakan saraf ini terlalu positif dan sulit untuk kembali ke keadaan semula (repolarisasi). Pada akhirnya menyebabkan serangga mengalami tremor yaitu gerakan yang tidak terkoordinasi yang menyebabkan serangga mengalami kelumpuhan (knockdown). ${ }^{6}$

Penyebab kelemahan pada saraf serangga juga dapat yang disebabkan oleh bahan aktif flavonoid (ermanin dan vitexin) yang terdapat pada ekstrak daun permot, dimana fungsinya adalah menghambat kerja enzim asetilkolinesterase. Asetilkolin yang dibentuk oleh sistem saraf pusat berfungsi untuk menghantarkan impuls dari sel saraf ke sel otot. Setelah impuls dihantarkan, proses dihentikan oleh enzim asetilkolinesterase yang memecah asetilkolin menjadi asetil ko-A dan kolin. Adanya flavonoid akan menghambat bekerjanya enzim ini sehingga terjadi penumpukan asetilkolin yang akan menyebabkan terjadinya gangguan pada sistem penghantaran impuls ke otot yang dapat berakibat otot kejang, terjadi paralisis dan berakhir pada kematian. Selain itu, juga dapat mengganggu aliran $\mathrm{Na}+$ (sodium) dalam sel saraf dan neurotransmiter (transmiter kimia) pada sinaps. ${ }^{8}$

Daun batang sereh (Cymbopogon nardus) merupakan tumbuhan yang mengandung minyak atsiri, dan bahan zat beracun yang berperan aktif adalah geraniol dan sitronella. ${ }^{9}$ Kandungan komposisi kimia yang terkandung dari ekstrak sereh minyak atsiri mengandung komponen antara lain limonen, sitral, metilheptenon, eugenol, metilester, kadinol, geraniol, sitronela, dipenten, kadien, eugenol. Ekstrak daun sereh juga mengandung silika $\left(\mathrm{SiO}_{2}\right)$ sebanyak $49 \%$ yang bersifat sebagai penyebab dehidrasi pada serangga. Kandungan geraniol dan sitronela yang pada konsentrasi tinggi memiliki keistimewaan sebagai antifeedant. ${ }^{10}$ Kandungan geraniol dan sitronela menyebabkan racun perut yang dapat membunuh rayap. ${ }^{11}$ Penelitian ini bertujuan untuk mengetahui bioefikasi campuran ekstrak daun permot dan daun batang sereh terhadap kematian kecoa Jerman. 


\section{Metodologi}

Bahan Penelitian. Tanaman daun permot (passiflora foetida) dan daun batang sereh (Cymbopogon nardus L.) didapatkan dari pasar tradisonal dan hewan uji coba kecoa jerman (Blatella germanica) yang dibeli didaerah $\mathrm{Jl}$. Pramuka, Kecamatan Mataram, Jakarta Timur pada bulan Juli 2019.

Persiapan Bahan dan Pembuatan Simplisia. Penelitian sebelumnya menyatakan bahwa penggunaan ekstrak daun permot saja pada mortalitas kecoa belum efektif, sehingga dalam penelitian ini ditambahkan ekstrak daun batang sereh. Ekstrak daun permot (Passiflora foetida) yang akan diteliti dan sudah dibersihkan terlebih dahulu kemudian dijemur untuk menguapkan zat cair yang masih terdapat pada bahan (bisa berupa getah ataupun air). Didiamkan selama 1-2 hari tanpa disinari oleh sinar matahari langsung agar tidak merusak kandungan dalam bahan. Setelah dijemur, bahan kemudian dihaluskan menjadi serbuk dengan blender. Pada sereh (Cymbopogon nardus). Sereh yang akan diteliti harus dicuci bersih terlebih dahulu. Sereh lalu dipotong kecilkecil kemudian dikeringkan dengan oven. Batang dan daun kemudian diambil lalu dihaluskan dengan blender.

Pelarutan Bahan dengan Etanol $\mathbf{7 0 \%}$. Sebanyak $100 \mathrm{~g}$ per bahan dimasukkan kedalam tabung erlenmeyer. Serbuk tanaman kemudian direndam dengan $75 \mathrm{~mL}$ pelarut etanol $70 \%$ di dalam tabung erlenmeyer selama 24 jam. Simpan di tempat sejuk yang terlindung dari sinar matahari langsung. Setelah dimaserasi dan remaserasi, hasilnya disaring dengan kertas saring. Hasil kemudian dievaporasi dengan rotary evaporator pada suhu $78^{\circ} \mathrm{C}$, kemudian di pindahkan ke cawan porselin yang telah ditimbang sebelumnya, dengan maksud untuk mempermudah perhitungan ekstrak kental yang akan diperoleh.

Pembuatan Larutan. Pembuatan larutan akan menggunakan campuran ekstrak yang telah dibuat ekstrak permot dan ekstrak sereh. Setiap $1 \mathrm{mg}$ ektrak akan dilarutkan kedalam $50 \mathrm{~mL}, 100 \mathrm{~mL}$, $200 \mathrm{~mL}$ dan $400 \mathrm{~mL}$. Akan dibuat larutan dengan kadar 500 ppm, 1000 ppm, 2000 ppm, dan 4000 ppm.
Perlakuan terhadap Hewan Uji Coba. Kelompok perlakuan terdiri dari 6 yaitu 1 kelompok kontrol negatif (tanpa diberi semprotan insektisida), 4 kelompok perlakuan campuran ekstrak daun permot dan ekstrak daun batang sereh dengan dosis bertingkat (500 ppm, 1000 ppm, 2000 ppm, dan 4000 ppm), 1 kelompok kontrol positif (diberi insektisida sintetis). Sebanyak 5 ekor kecoa Jerman (Blatella germanica) masing-masing dimasukkan ke dalam 6 akuarium kelompok perlakuan. Satu akuarium dibiarkan tidak diberi perlakuan untuk dijadikan sebagai kontrol negatif. Lalu 4 akuarium berisi kecoa disemprot dengan larutan pestisida yang sudah dibuat dengan dosis bertahap sampai habis langsung ke kecoa yang digunakan untuk subjek uji coba. Lalu akuarium terakhir disemprot dengan insektisida sintetik komersial berbahan campuran praletin $0,170 \%$, DAlletrin $0,135 \%$, dan sipermetrin $0,100 \%$ (yaitu kandungan di salah satu jenis insektisida yang sudah ada di pasaran). Kemudian kecoa diamati setelah 10 menit pertama penyemprotan, dan dilanjutkan tiap jam sampai 6 jam dan 24 jam. Diamati hingga kecoa terbalik dan mati.

Parameter yang Diperiksa. Parameter yang diamati adalah persentase kematian kecoa jerman sebelum dan sesudah pemberian campuran ekstrak daun permot (Passiflora foetida) dan daun batang sereh (Cymbopogon nardus).

Analisis Data. Data penghitungan kecoa Jerman yang mati menggunakan uji One Way Anova, yaitu untuk melihat adanya perbedaan yang bermakna antara kelompok kontrol dan kelompok perlakuan. Apabila hasil terdapat perbedaan yang bermakna, maka dilanjutkan dengan uji Beda Nyata Terkecil (BNT). Untuk mengetahui dosis efektif bahan yang digunakan dilakukan uji Probit menggunakan SPSS 25.

\section{Hasil}

Untuk mengetahui kemungkinan kadar yang dibutuhkan untuk mendapatkan tingkat kematian $50 \%\left(\mathrm{LC}_{50}\right)$ dan $90 \%\left(\mathrm{LC}_{90}\right)$, maka dilakukan perhitungan dengan menggunakan uji probit dengan menggunakan program SPSS 25. Dari hasil uji probit, didapatkan hasil seperti yang terlihat pada Tabel 1. 
Tabel 1. Hasil Uji Probit yang Menunjukan LC 50 $_{50}$ Hingga LC C $99_{9}$

\begin{tabular}{|l|l|}
\hline Probability & Estimate \\
\hline 500 & 341.390 \\
\hline 550 & 385.379 \\
\hline 600 & 435.887 \\
\hline 650 & 495.057 \\
\hline 700 & 566.128 \\
\hline .750 & 654.312 \\
\hline 800 & 768.765 \\
\hline 850 & 927.679 \\
\hline 900 & 1175.099 \\
\hline 950 & 1244.153 \\
\hline 920 & 1323.778 \\
\hline 930 & 1417.224 \\
\hline 940 & 1529.408 \\
\hline 950 & 1668.233 \\
\hline 960 & 1847.517 \\
\hline 970 & 2094.540 \\
\hline .980 & 2474.783 \\
\hline .990 & 3219.031 \\
\hline
\end{tabular}

Dari hasil uji probit, diperoleh data bahwa dengan dosis sebanyak 341,390 ppm, sudah cukup mampu untuk mencapai $\mathrm{LC}_{50}$, atau tingkat kematian 50\%. Menurut rekomendasi WHO, insektisida dapat dikatakan efektif memiliki daya bunuh apabila dapat membunuh sebanyak $90 \%$ dari sampel atau mencapai $\mathrm{LC}_{90}$, atau tingkat kematian mencapai 90\%. Dari hasil Probit didapatkan $\mathrm{LC}_{90}$ atau kadar yang dibutuhkan untuk mencapai tingkat kematian 90\% adalah 1175 ppm.

Hasil penelitian dapat dilihat pada Gambar 1 , yaitu memperlihatkan grafik rata-rata presentase kematian kecoa semua kelompok setelah diberikan perlakuan.

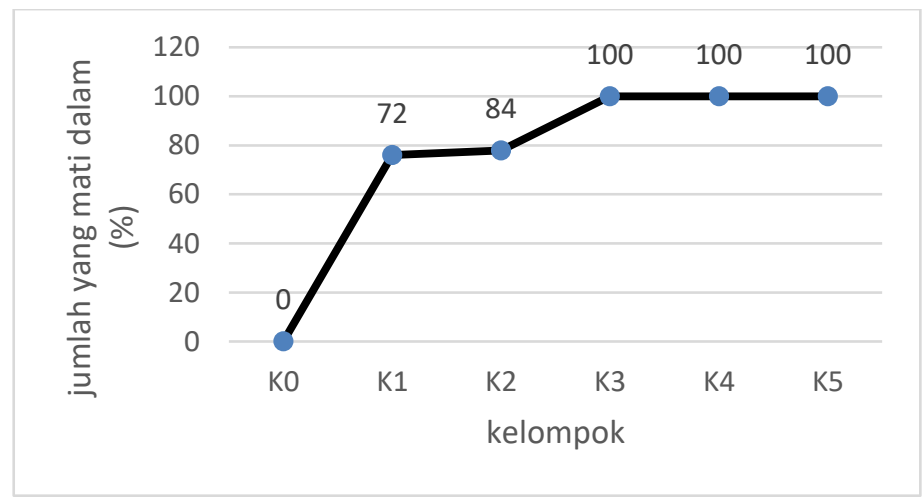

Gambar 1. Grafik Rerata Kematian (\%) Kecoa Jerman Dewasa Setelah Pemaparan Insektisida. Kelompok $0=$ tanpa paparan, kelompok 1= daun permot dan sereh $500 \mathrm{ppm}$, kelompok $2=$ daun permot dan sereh 1000 ppm, kelompok 3= daun permot dan sereh $2000 \mathrm{ppm}$, kelompok 4= daun permot dan sereh $4000 \mathrm{ppm}$, dan kelompok $5=$ insektisida komersial)

Dari Gambar 1 dapat dilihat bahwa kematian kecoa $100 \%$ terjadi pada kelompok perlakuan yang disemprot dengan campuran daun permot dan sereh dosis 2000 ppm, 4000 ppm dan kelompok kontrol positif (disemprot dengan menggunakan insektisida sintetik komersial), yang berarti efektif memiliki daya bunuh terhadap kecoa Jerman.
Setelah mangetahui dosis yang dibutuhkan untuk mencapai $\mathrm{LC}_{90}$ maka akan dilakukan uji One Way Anova untuk mengetahui efektivitas daya bunuhnya pada kelompok kontrol maupun kelompok perlakuan (Tabel 2). 
Tabel 2. Hasil Uji One Way Anova pada Kecoa Jerman yang Terpapar Campuran Ekstran Daun Permot dan Daun Batang Sereh

\begin{tabular}{llcccc}
\hline & & Jumlah & df & Rerata & F \\
\hline Antara & Kombinasi & 37546,667 & 5 & 7509,333 & $32,183 * *$ \\
kelompok & Kontras & 26404,571 & 1 & 26404,571 & 113,162 \\
& Deviasi & 11142,095 & 4 & 2785,524 & 11,938 \\
& & & & & \\
$\begin{array}{l}\text { Dalam } \\
\text { kelompok }\end{array}$ & & 5600,000 & 24 & 233,333 & \\
Total & & 43146,667 & 29 & & \\
\hline
\end{tabular}

Keterangan: $* *$ berbeda sangat bermkna $(\mathrm{p}<0,01)$

\section{Pembahasan}

Dari hasil uji Anova, didapatkan P-Value menunjukan 0,00. Hal ini menunjukan adanya perbedaan signifikan antara kelompok kontrol dengan kelompok perlakuan.

Karena ditemukan adanya hasil menunjukan adanya perbedaan yang bermakna antara kelompok kontrol dengan kelompok perlakuan, maka hasil percobaan perlu dilanjutkan dengan uji Post-Hoc. Dari hasil uji Post-Hoc, didapatkan adanya perbedaan diantara kelompok kontrol negatif (tanpa perlakuan) dengan kelompok insektisida campuran ekstrak daun permot dan daun batang sereh. Tidak ada perbedaan yang bermakna antara kelompok 3 (dosis 0,20\%) dengan kelompok 4 (dosis 0,40\%), dan kelompok 5 (kontrol positif).

Dari hasil penelitian didapatkan bahwa dosis yang efektif untuk mencapai kematian kecoa sebanyak 90\% sebesar 1175 ppm. Ketika diberikan perlakuan semprotan insektisida baik berbahan sintetis maupun berbahan campuran ekstrak daun permot dan daun batang sereh dosis $0,02 \%$ dan $0,04 \%$, ada beberapa kecoa secara spontan langsung terbalik dan mati. Kejadian tersebut disebabkan oleh efek senyawa kimia aktif yang terdapat pada ekstrak daun permot seperti ermanin, vitexin, harmalin, harmin yang diduga memiliki aktivitas mekanisme kerja neurotoksin yang menghambat aktivitas enzim asetilkolinesterase, sehingga terjadi fosforilasi asam amino serin pada pusat asteratik enzim tersebut.

Cara kerja zat kimia yang terkandung dalam ekstrak daun permot adalah mempengaruhi sistem saraf (neurotoksin). Sistem saraf adalah suatu organ yang digunakan untuk merespon rangsangan baik dari luar maupun dari dalam sehingga serangga dapat hidup dan berkembang. Sistem saraf terdiri dari banyak sel saraf (neuron) yang saling berhubungan yang menyebar ke seluruh tubuh. Secara tipikal bentuk neuron di salah satu ujungnya berupa semacam serabut yang disebut dendrit dan diujung lain memanjang dan ujungnya bercabang-cabang disebut akson. Antar neuron berhubungan melalui aksonnya. Titik dimana dua neuron berhubungan disebut sinap. Ujung akson yang berhubungan neuron lainnya disebut pre sinap sedangkan bagian dari neuron yang berhubungan dengan presinap disebut postsinap. Impul saraf berjalan dari satu neuron ke neuron berikutnya sepanjang akson melalui sinap. Di daerah sinap impul saraf diteruskan oleh neurotransmitter yang banyak jenisnya. Berjalannya simpul saraf merupakan proses yang sangat kompleks. Proses ini dipengaruhi oleh keseimbangan ion-ion $\mathrm{K}^{+}, \mathrm{Na}^{+}, \mathrm{CA}^{2+}, \mathrm{Cl}^{-}$, berbagai macam protein, enzim, neurotransmitter, dan lainlainnya yang saling mempengaruhi. ${ }^{12}$ Gangguan pada salah satu faktor mengakibatkan impul saraf tidak dapat berjalan secara normal. Pada keadaan normal kanal ion natrium tersusun dari protein yang memiliki banyak gugus bermuatan. Dimana pada kanal ion natrium tedapat dua kanal yaitu kanal aktivasi dan inaktivasi. Kedua kanal ini harus terbuka secara bersamaan agar natrium dapat masuk. Ketika terdapat depolarisasi yang terjadi karena adanya rangsangan, kanal natrium akan terbuka dan natrium akan masuk secara cepat hingga mencapai hiperpolarisasi dan kanal inaktivasi akan menutup. Sehingga serangga tidak mampu merespon rangsangan. ${ }^{12}$

Gejala keracunan akibat neurotoksin tersebut timbul karena adanya penimbunan asetilkolin yang menyebabkan gangguan sistem saraf pusat, kejang, kelumpuhan pernafasan, dan kematian. Bahan aktif ini dapat mengganggu aliran $\mathrm{Na}^{+}$dalam sel saraf dan neurotransmitter pada sinaps. Ketidakaktifan saraf ini dikarenakan saraf terlalu positif dan sulit untuk repolarisasi (kembali ke keadaan semula) pada akhirnya, hal ini menyebabkan tremor pada 
serangga, yaitu gerakan yang tidak terkoordinasi yang menyebabkan serangga mengalami kelumpuhan (knockdown).

Kandungan geraniol dan sitronela dari sereh tidak membunuh serangga secara cepat, tetapi berpengaruh mengurangi nafsu makan, pertumbuhan, daya reproduksi, proses ganti kulit, hambatan menjadi serangga dewasa, sebagai pemandul, serta mudah diabsorsi oleh tanaman. Sedangkan, pada konsentrasi rendah, geraniol dan citronella menyebabkan racun perut yang dapat membunuh rayap. Ekstrak daun sereh juga mengandung silika $\left(\mathrm{SiO}_{2}\right)$ yang bersifat sebagai penyebab dehidrasi pada serangga. ${ }^{5}$

Dengan campuran kedua ekstrak diatas, setelah kecoa terpapar ermanin, vitexin, harmalin, harmin yang mengalami kelumpuhan, kecoa mengalami paparan dari sereh yang membuat kecoa dehidrasi. Daun sereh juga meracuni pakan dan air untuk kecoa sehingga membunuh kecoa yang tidak langsung mati setelah diberi perlakuan.

Pengendalian hama yang merupakan ramuan dari tanaman atau terbuat dari bahan - bahan alami memerlukan biaya yang murah, mudah dibuat, tidak menyebabkan pencemaran lingkungan dan tidak menyebabkan serangga menjadi resisten. ${ }^{13}$ Penggunaan jenis insektisida dalam jangka waktu panjang dapat menimbulkan resisten, seperti jenis insektisida sintetik golongan organofosfat dan karbamat. ${ }^{14}$ Mekanisme terjadinya resistensi serangga terhadap insektisida diklasifikasikan pada tiga kelompok yaitu: resistensi kutikular (penurunan penetrasi), resistensi metabolik dan perubahan sisi target. Dalam resistensi metabolik terjadi perubahan enzim baik secara kualitatif maupun kuantitatif yang memetabolisme insektisida sebelum mencapai sisi target. Enzimenzim tersebut bertanggung jawab mendetoksikasi xenobiotik. Ada 3 enzim yang termasuk dalam kelompok ini yaitu: esterase, glutation $\mathrm{S}$ transferase dan oksigenase. Enzim yang paling banyak berperan dalam resistensi serangga terhadap organofosfat adalah esterase. ${ }^{15}$

Mekanisme kerja organofosfat tersebut adalah dengan menghambat enzim hidroksi asetilkolinesterase, yang merupakan enzim pada sistem saraf pusat dan perifer yang berfungsi menghidrolisis neurotransmitter asetilkolin. ${ }^{16}$ Asetilkolin merupakan neurotransmiter yang terdapat di antara ujung saraf dan otot serta berfungsi meneruskan rangsangan saraf. ${ }^{17}$ Jika kemampuan menghidrolisis asetilkolin menurun, menyebabkan asetilkolin lebih lama di reseptor, dan akan memperpanjang efek rangsang saraf kolinergik pada preganglionik dan postganglionic..$^{18}$ Jenis pestisida organofosfat dan karbamat memiliki cara kerja yang sama, yaitu menghambat penyaluran impuls saraf dengan cara mengikat kolinesterase, sehingga tidak terjadi hidrolisis asetilkolin. ${ }^{17,19}$

\section{Simpulan}

Bahan-bahan aktif yang terkandung dalam ekstrak permot seperti ermanin, vitexin, harmalin, harmin dan juga minyak astiri sebagai bahan aktif yang terkandung dalam daun dan batang batang sereh dapat digunakan sebagai bioinsektisida terhadap kecoa Jerman. Diperoleh nilai $\mathrm{LC}_{90}$ sebesar $1175 \mathrm{ppm}$ yang merupakan dosis efektif untuk membunuh kecoa Jerman. Seluruh kecoa mati baik kelompok perlakuan insektisida sintetik komersial maupun kelompok insektisida campuran ekstrak daun permot (Passiflora foetida) dan daun ekstrak batang sereh (Cymbopogon nardus) pada kurun waktu kurang dari 1 jam.

\section{Daftar Pustaka}

1. Sahara S, Indriati G, Rahayu R.Efektivitas ekstrak sereh wangi (Cymbopogon nardus $\mathrm{L}$. Rendle) terhadap kecoa Jerman (Blattella germanica L.) Populasi VCRU-WHO, GFAJKT dan HHB-JKT. Sumatra Barat: 2014. h.1-2.

2. Susilowati RP, Puspa MS. Uji bioinsektisida berbahan ekstrak daun permot (Passiflora foetida) terhadap kematian kecoa Jerman (Blatella germanica). Jakarta: Seminar Nasional Biologi UKSW. 2018 h.1-2.

3. Valles S. German cockroach, Blattella germanica (Linnaeus) (Insecta: Blattodea: Blattellidae), The Institute of Food and Agricultural Sciences (IFAS) Extention. 2017; 2(2): 1-4.

4. Jacobs S. German Cockroaches (On-line). Entomology Notes, Pennsylvania State University. 2007.

5. Klasifikasi Daun Permot (Passiflora foetida L). Diakses pada tanggal 10 maret 2018. http://www.modulbiologi.com/klasifikasidan-ciri-ciri-morfologi-permot/

6. Susilowati RP. Efektivitas ekstrak daun permot (Passiflora foetida) terhadap mortalitas larva nyamuk Ae. aegypti. Laporan Penelitian. Jakarta: Fakultas Kedokteran, 
Universitas Kristen Krida Wacana. 2013. h.13.

7. Susilowati RP. Efektivitas daun permot (Passiflora foetida) sebagai obat nyamuk dan pengaruhnya pada sel darah mencit. Artikel Penelitian. Jakarta: Fakultas Kedokteran, Universitas Kristen Krida Wacana. 2017. h.23.

8. Susilowati RP, Hartono B. Daya bunuh ekstrak daun permot (Passiflora foetida) terhadap larva nyamuk Culex quinquefasciatus. Jakarta: Fakultas Kedokteran, Universitas Kristen Krida Wacana. 2017. h.417-2.

9. Nurkartika N. Khasiat minyak atsiri daun wangi (Cymbopogon nardus L) sebagai anti fungi, sebagai insektisida pengusir lalat rumah dan pengusir nyamuk. Semarang: Jurusan Biologi Fakultas Matematika dan Ilmu Pengetahuan Alam.

10. Saenong MS. Tumbuhan Indonesia potensial sebagai insektisida nabati untuk mengendalikan hama kumbang bubuk jagung (Sitophilus spp.). Jurnal Litbang Pertanian, 2016; 35(4):134.

11. Hutabarat NK, Oemry S, Pinem MI. Uji efektivitas termitisida nabati terhadap mortaliatas rayap (Coptotermes curvinagthus Holmgren) (Isoptera: Rhinotermitidae) di laboratorium. Jurnal Online Agroekoteknologi, 2015;3(1):103-11.

12. Djojosumarto P. Panduan lengkap pestisida \& aplikasinya. Jakarta: Agro Media Pustaka; 2008.

13. Astuti W, Widiyastuti CR. Peptisida organik ramah lingkungan pembasmi hama tanaman sayur. Semarang: Fakultas Teknik, Universitas Negeri Semarang. 2016. H. 1771.

14. Hasibuan R. Insektisida pertanian. Yogyakarta: Plantaxia; 2012. 2012. 2012.h.30-1.

15. Lesmana SD. Resistensi Aedes aegypti terhadap Insektisida Golongan Organofosfat. Pekan Baru: Bagian Bagian Parasitologi FK Universitas Riau. 2010. h.10-2

16. Jett DA. Neurotoxic pesticides and neurologic effects. Neurol Clin. 2017;29(2011):667-77.

17. Raini M. Toksikologi pestisida dan penanganan akibat keracunan pestisida. Media Litbangkes. 2007;17(1):10-8.

18. Erwin I, Kusuma D. Inhibitor asetilkolinesterase untuk Menghilangkan
Efek Relaksan Otot Non-depolarisasi. CDK. 2012;39(5):333-9.

19. Wiadi IN, Muliarta IM. Fluktuasi tekanan darah dan efek performa neurobehavior pada paparan pestisida organofosfat jangka panjang pada remaja di daerah pertanian. EJurnal Med. 2017;6(4):63-72. 